\title{
APPLIED EU QUALITY SCHEMES AND ORGANIC PRODUCTS ON ROMANIAN MARKET ${ }^{1}$
}

\author{
Dan-Marius Voicilas ${ }^{2}$, Cornelia-Florentina Alboiu ${ }^{3}$
}

\begin{abstract}
Summary
The aim of the paper is to identify the market potential for products produced and processed according to the EU quality schemes (organic products, PDO, PGI and TSG) on Romanian market. It provides a description of EU and national policies related to development of new markets like organic, PDO, PGI and TSG products, in particular PGI market. The structure of the paper contains an analysis of the organic products and, separately, the analysis of PGI products in Romania, with examples of products under EU quality schemes. During the analysis, we focused on the following aspects: legal frame, institutions and implementation of the quality schemes, supply side, demand side, trade, investments in the field, problems identified and tendencies. It puts in evidence the main characteristics of the country, tendencies, challenges and particularities, which define the groups of products analysed. The example given in text tries to show practical aspects and ways of implementation of the EU quality schemes, for Romania. The paper provides general conclusions resulted from the EU quality schemes implementations in Romania. In the same time, we identify a few difficulties regarding the expansion of the market. By present paper we open new discussions about trends in the field, future developments and models for a good standard of life.
\end{abstract}

Key words: EU, Quality schemes, Organic products, PGI, Romania.

JEL: Q13, Q18

1 Work under FP 7 COMPETE Project "International comparisons of product supply chains in the agro-food sectors: determinants of their competitiveness and performance on EU and international markets", Grant Agreement No. 312029 (http://compete-project.eu/), with funding from the European Community and the Ministry of National Education from Romania through the Executive Unit for Funding Higher Education, Research, Development and Innovation, project coordinated by IAMO (Halle/Saale-Germany), partner Institute of Agricultural Economics Romanian Academy (Team leader: D. M. Voicilas), Working paper "EU quality schemes: market potential for products produced and processed", 2014.

2 Associate professor, Ph.D., Senior researcher III, Romanian Academy - Institute of Agricultural Economics, "Casa Academiei" - Calea 13 Septembrie 13, sector 5, Bucharest, Romania, Phone: +40 7223981 19, E-mail: dmvoici@yahoo.com

3 Ph.D., Senior researcher II, Romanian Academy - Institute of Agricultural Economics, "Casa Academiei" - Calea 13 Septembrie 13, sector 5, Bucharest, Romania, Phone: +40 7213791 20, E-mail: coraalboiu@yahoo.com

EP 2014 (61) 2 (381-395) 


\section{Introduction}

This paper aims to identify the market potential for products produced, processed and traded according to the EU quality schemes, represented by organic products, protected designation of origin (PDO), protected geographical indication (PGI) and traditional speciality guaranteed (TSG), in Romania.

First, the paper provides an overview about institutional and policy framework: legislation, institutions dealing with these, associations of producers, rules, assistance, funding, aim of policy concerning organic product and patterns in development of organic cultivated area and similar developments.

Second, the paper provides details about market developments of organic products and PGI products.

The hypothesis we have in view for the elaboration of the present study clearly put in evidence the importance of the products mentioned above both for producers and consumers. The business in this field has double advantage, for both sides. In the same time, we would like to envisage that, the increase of the visibility of the products has a decisive role and it can direct influence the increase of the incomes for producers.

We divided the paper in two main parts: one focus on organic products and one on PGI products. For each part, we tried to cover demand, supply, trade and challenging issues. Demand covers overall trends and attitude toward the mentioned products, expenditures in the last years, category of consumers who primarily buy them, which products are mostly bought, where, in kind of markets such as spot market, super market and similar. Supply side covers producers and their developments in production such as enterprises/ farms, their number, which part of agricultural farms or enterprises, cultivated area, size, and development in the last years. In addition, it covers trade volume in total, at the national markets, intra- or extra- EU sales, problems related to production and trade of the products, and investment in research concerning ecological cultivation.

\section{Theoretical background}

Organic foods are foods that are produced using methods of organic farming - with limited modern synthetic inputs such as synthetic pesticides and chemical fertilizers. Organic foods are also not processed using industrial solvents, or chemical food additives.

Three European Union schemes of geographical indications and traditional specialities, known as protected designation of origin (PDO), protected geographical indication (PGI), and traditional specialties guaranteed (TSG), promote and protect names of quality agricultural products and foodstuffs. ${ }^{4}$ They are based on the legal framework provided by the EU Regulation No 1151/2012 of the European Parliament and of the Council of 21 November 2012 on quality schemes for agricultural products and foodstuffs. ${ }^{5}$ This

4 http://ec.europa.eu/agriculture/quality/schemes/index_en.htm

5 http://eur-lex.europa.eu/LexUriServ/LexUriServ.do?uri=OJ:L:2012:343:0001:0029:en 
Regulation (enforced within the EU and being gradually expanded internationally via bilateral agreements between the EU and non-EU countries) ensures that only products genuinely originating in that region are allowed to be identified as such in commerce. The purpose of the law is to protect the reputation of the regional foods, promote rural and agricultural activity, help producers obtain a premium price for their authentic products, and eliminate the unfair competition and misleading of consumers by non-genuine products, which may be of inferior quality or of different flavour.

The protected geographical indication (PGI) is the name of an area, a specific place or, in exceptional cases, the name of a country, used as a description of an agricultural product or a foodstuff. The products must be characterised by:

- comes from such an area, place or country,

- has a specific quality, goodwill or other characteristic property, attributable to its geographical origin,

- whose production, processing or preparation takes place within the determined geographical area.

In other words, to receive the PGI status, the entire product must be traditionally and at least partially manufactured (prepared, processed or produced) within the specific region and thus to acquire unique properties.

The paper evaluates and discusses all the concepts mentioned above, the policies in the field and tendencies observed during the last years.

\section{Methodology}

For the analysis, we use long time series data based on statistical data provided by the National Institute of Statistics of Romania, the Ministry of Agriculture and various publications in this field. We split the analysis of organic products in two distinct periods: the market before European Union (EU) accession and the market after EU accession. At the end of the paper we give practical examples of PGI in Romania. Last but not least, we want to mention that we use the partial results from the FP7 Project COMPETE (International comparisons of product supply chains in the agro-food sectors: determinants of their competitiveness and performance on EU and international markets), leaded by IAMO (Halle/Saale-Germania), which started in 2012 and lasts three years (www.compete-project.eu), (Alboiu et al., 2014). The project is the result of the cooperation of the consortium established and comprises sixteen institutions from ten countries, financed by European Communities and co-financed by National Ministry of Education. The Institute of Agricultural Economics-Romanian Academy is partner in this consortium.

\section{Legal framework}

At national level, together with the signing up of the Association Agreement and the initiation of the EU accession negotiations - Romania's legislation had to get in line with 
the EU legislation. Following this process, at present, Romania's legislation complies with EU requirements and orientations.

The legal basis of the organic farming system was established in the 1990s by the Commission Regulation (EC) no. 2092/1991 regarding organic farm production and the indications for their presentation as agricultural and agri-food products.

The main normative acts produced for organic products market are: Government's Emergency Ordinance (OUG) no. 34/2000 on the organic agri-food products, approved by Law no. 38/2000; Government's Decision (HG) no. 917/2001, for the approval of the Methodological Norms for the application of provisions from OUG no. 34/2000 regarding the organic agri-food products; The Joint Order no. 417/2002 and no. 110/2002 of the Minister of Agriculture and of the President of the National Authority for Consumers' Protection; Order no. 70/2002 of the Minister of Agriculture on the establishment of the Commission for Organic Farming Development in Romania; Order no. 527/2003 of the Minister of the Agriculture for the approval of the Rules on the inspection and certification system and the accrediting conditions for the inspection and certification bodies in organic farming; Order no. 721/2003, of the Minister of the Agriculture for the approval of Rules on the import and export of organic agri-food products; Order no. 153/2006 regarding the approval of the competency of the Commission for accrediting the inspection and the certification bodies in the organic farming sector, which inspects and controls the operators on Romania's territory; Order no. 317/2006 regarding the modification and completion of the Annex to the Order of the Ministry of Agriculture and of the President of the National Authority for Consumers' Protection no. 417/110/2002, for the approval of the Specific labelling rules for the organic agri-food products; OUG no. 62/2006 for the modification and completion of OUG no. $34 / 2000$ on the organic agri-food products; Law no. 513/2006 on the approval of OUG no. $62 / 2006$ for the modification and completion of OUG no. 34/2000 regarding the organic agrifood products; Order no. 219/2007 on the approval of Rules regarding the organic farmers' official registration. All these provide information, rules and norms necessary in this field like: the authority responsible for organic farming; the general rules and principles of organic production; the duration of the conversion period; the inspection and certification system; the list of accepted products to be used by the organic farming practice; the list of ingredients and processing methods that can be used in the preparation of organic foodstuffs; sanctions etc.

The legal framework for EU quality schemes is provided by the EU Regulation No 1151/2012 of the European Parliament and of the Council of 21 November 2012 on quality schemes for agricultural products and foodstuffs.

In Romania, the legal frame comprises: MADR Order no. 690/2004 for the approval of the conditions and criteria for certifying traditional products; HG no. 828/2007, establishing a system for the protection of geography indications and designations of origin for agricultural products and foodstuffs; HG no. 134/2008 on the traditional specialties guaranteed for agricultural products and foodstuffs; MADR Order No.160/2008 - Procedure for registration and documentation for obtaining protection of traditional specialties guaranteed, procedure declaration of opposition nationally and procedure for submission to the European Commission 
of the application for registration of traditional specialty guaranteed in order to gain protection in the European Union, as well as specific rules about design and use of national logo.

\section{Policy and institutional framework}

In Romania, the government, the civil society and the business environment are becoming increasingly aware of the need to promote organic farming.

The governmental policy on organic market is elaborated and coordinated by Ministry of Agriculture and Rural Development (MADR), under which the Office of the National Authority for Organic Products (ANPE) is operating, which is the authority in charge of the organic farming sector. ANPE is collaborating (or collaborated) with different agencies, education and research institutions, foundations, among which we can list the following:

- The National Agency For Agriculture Consultancy - ANCA (no longer exist nowadays);

- The Academy of Agricultural and Forestry Sciences - ASAS;

- Higher education institutions, agricultural research institutes and stations;

- The National Organic Farming Federation, whose activity is based on the "sustainable development principle", a development type which should not disable the next generations' access to a clean environment.

The Ministry of Agriculture establishes an action plan for the development of the domestic market of organic products, which includes:

- The intensification of actions promoting the organic farming concept;

- The improvement of information on organic farming practice, and the qualification of the participants in this sector;

- The increase of areas under the experimental modules "organic micro-farms";

- The delimitation of organic farming areas;

- Support to farmers during the conversion period;

- The creation of an information system accessible to farmers.

The organic market in Romania is a relatively new market, with continues changes in terms of institutions and policies elaborated. This is the reason why are necessary deeper analysis on results and tendencies in the field.

As organic farming contributes to sustainable development, through an increase of biodiversity, soil fertility and environmental protection, the organic farmers are supported through the agroenvironmental programs of the European Commission (EC). Thus, starting with 2007, the year of Romanian accession into EU, organic farmers benefit from a compensatory premium per hectare (and by crops), in order to make up for the income losses incurred during the conversion period and for the certified production, through the National Rural Development National Plan (PNDR) - Axis 2 - the agro-environmental sub-measure, from the European Agricultural Fund for Rural Development (EAFRD), non-refundable support in conformity with the Commission Regulation (EC) no. 1698/2005.

EP 2014 (61) 2 (381-395) 
At the same time, EU provides support for the promotion of organic products, through cofinancing programs, with a 50\% funding from the EC, $20 \%$ from professional organization, and $30 \%$ from the state budget, in conformity with the procedure of the Commission Regulation (EC) no. 1071/2005.

As regards the quality schemes, we would like to mention that the quality policy is one of the 16 sub-community policies on agriculture.

At national level, the quality schemes implementation is realised by MADR and its specialised institutions. Among them, we mention the National Office of Romanian Traditional and Ecological Products. It is a public institution with legal personality under MADR, financed from the state budget. As a specialized public institution, provides ${ }^{6}$ :

• promoting the concept of "product quality" and "green products";

- technical assistance to producers/processors in developing documentation under Community and national legislation to require PGI, PDO and TSG Romanian agricultural products or foodstuffs at national and EU level;

- technical assistance in developing projects to promote Romanian traditional and organic products;

- promoting the image of Romanian traditional and organic products;

- verification of compliance documentation designed to require the protection of designations of origin for agricultural products and foodstuffs Romanian national and Community provisions and national legislation;

- dissemination of national and Community provisions on Romanian traditional and organic products among farmers and processors;

seminars, courses and training and information for the group of producers or processors, farmers associations.

\section{Organic market organization}

At the beginning of the year 2007, the following organizations were registered at MADR, with attributes or concerns in organic farming, rural development, environment protection and sustainable development (Voicilas, 2007b): The Association for ecological agriculture "agri-eco", with the headquarters in Cluj Napoca, the professional Organization „Agroecologia” - Cluj Napoca, the Association of the bio-farmers in Romania „BIOTERRA” - Cluj' county, the Romanian Association for Sustainable Agriculture Călăraşi County, the Association „Terra Verde” - Bucharest, the Association of the Biopoultry breeders in Romania - BIOAVIROM - Ilfov County, the Association for the organic farming development in Romania, "Ecofocus" - Bucharest, Ecorural - Bucharest, the Association for the Environmental Protection and ecological agriculture „TER" Bucharest, the Foundation „Mama Terra” - Bucharest, ,The National Association of the Agricultural Consultants" - Bucharest, the Academic Foundation for Rural Progress

6 Oficiul National al Produselor Traditionale si Ecologice Romanesti (National Office for Traditional and Organic Romanian Products), http://www.onpterbv.ro/ 
„TERRA NOSTRA” - Iaşi, „The Ecologist Society in Maramureş” - Baia Mare, „The Foundation for Rural Development in Romania” - Bucharest, „The Ecological Group for Cooperation Bucovina” - Suceava, the Foundation „Business School Mehedinți” Drobeta Turnu Severin, the Society „Avram Iancu” - Cluj Napoca, the Foundation „,The Operation Romanian Villages”- Bacău county, ,,The Ecological Club Transylvania”-Cluj Napoca, ,The Romanian Rural Foundation” - Timişoara, „Bioclub Cluj” - Cluj Napoca, „the Group of Gardeners Biodynamics” - Târgu Mureş, „the Romanian Association for Applied Biofarming” - Arad county, „the Centre for Ecological Consulting Galaţi” Galați, „the Association for Environmental and Nature Protection” - Târgu Mureş, the Foundation „Divers Eco” - Maramureş county, the Foundation „Noema Consulting” - Cluj Napoca, the Association „Albina” (the „Bee”) - Bucharest, the Association for Environment Protection and Preservation of Resources - Bucharest.

In Annex 1, we present the list of the organizations in organic agriculture, rural development, environmental protection, and durable development, at the end of 2012.

Organic operators (farmers) were registered at MADR and classified by three large categories of products: crop, livestock and beehive products. The farmers are organized either as independent producers, physical entities, or as family associations or commercial companies as legal entities under the form of limited liability companies or joint stock companies. Not all the counties are included in this evidence. Most organic farmers are from a few counties: Suceava (North), Mureş and Sibiu (Centre), Tulcea and Constanța (South-Est).

\section{Supply of organic products in Romania}

The data provided by MADR reveal the increasingly importance of this activity sector for the domestic producers. The positive evolutions of the areas and production in the organic farming sector prove the existing potential, initiative, development prospects and increasing demand from the consumers' part.

In the tables 1, 2 and 3 we present the dynamic of the field, which proves the above statements.

Table 1. Areas under organic farming system before EU accession (2000-2006)

\begin{tabular}{|c|c|c|c|c|c|c|c|}
\hline \multirow{2}{*}{ Specification } & \multicolumn{6}{|c|}{ Yearly Index } & \multirow{2}{*}{2006} \\
\hline & 2000 & 2001 & 2002 & 2003 & 2004 & 2005 & \\
\hline Total area, out of which: & $100(17,438 \mathrm{ha})$ & 1.65 & 2.51 & 3.28 & 4.23 & 6.33 & 8.20 \\
\hline Cereals & $100(4,000 \mathrm{ha})$ & 2.00 & 3.00 & 4.00 & 5.12 & 5.52 & 4.08 \\
\hline Pastures and fodder crops & $100(9,300 \mathrm{ha})$ & 1.51 & 2.15 & 2.58 & 3.37 & 4.55 & 5.51 \\
\hline Oilseeds and protein crops & $100(4,000 \mathrm{ha})$ & 1.58 & 2.50 & 3.90 & 5.02 & 5.65 & 5.97 \\
\hline Vegetables & $100(38 \mathrm{ha})$ & 2.63 & 18.40 & 5.26 & 7.89 & 11.58 & 18.95 \\
\hline Fruits (sour/cherries, apples) & - & - & 100 (50 ha) & 2.00 & 4.00 & 8.64 & 5.84 \\
\hline Spontaneous flora collection & $100(50 \mathrm{ha})$ & 2.00 & 6.00 & 8.00 & 10.00 & 352.60 & 774.00 \\
\hline Other crops & $100(50 \mathrm{ha})$ & 6.00 & 16.00 & 18.00 & 18.00 & 97.68 & 242.00 \\
\hline
\end{tabular}

Source: Own calculation based on MADR and INS (National Institute of Statistics) data. 
Land areas (Table 1) increased in the mentioned period. The trend is increasing and the perception of these crops as an alternative activity and income source is positive (Voicilas, 2007a). Comparing the objectives established by the government's strategy with the field results, we could say that the objectives were reached; the bases were created for the development of this activity and for the use of the market niches, both on the domestic and world markets.

As in the case of land areas, productions (Table 2) continuously increased in the investigated period. Although the production levels were much higher at the moment of accession into EU than those obtained 5-6 years before, the domestic supply cannot totally meet the demand, which makes it possible for the imported organic products to penetrate the Romanian market, as we shall see later on (Voicilas, 2007a). For instance, total crop production increased by 12 times, oilseeds and protein crops by 13 times, vegetables by 14 times. In the same time, an incredible grow had spontaneous flora collection with almost 125 times.

Table 2. Organic farm production before EU accession (2000-2006)

\begin{tabular}{|l|c|c|c|c|c|c|c|}
\hline \multirow{2}{*}{ Specification } & \multicolumn{6}{|c|}{ Yearly Index } & \multirow{2}{*}{$\mathbf{2 0 0 6}$} \\
\cline { 2 - 8 } & $\mathbf{2 0 0 0}$ & $\mathbf{2 0 0 1}$ & $\mathbf{2 0 0 2}$ & $\mathbf{2 0 0 3}$ & $\mathbf{2 0 0 4}$ & $\mathbf{2 0 0 5}$ & \\
\hline Total crop production, out of which: & $100(13,502$ to $)$ & 1.81 & 2.39 & 2.25 & 6.46 & 9.77 & 12.34 \\
\hline -Cereals, out of which: & $100(7,200$ to $)$ & 1.74 & 2.22 & 2.00 & 5.69 & 7.64 & 6.73 \\
\hline Export & - & - & - & - & $\begin{array}{c}100 \\
(7,100 \text { to })\end{array}$ & 1.56 & 2.55 \\
\hline $\begin{array}{l}\text {-Oilseeds and protein crops, } \\
\text { out of which: }\end{array}$ & $100(5,500$ to $)$ & 1.31 & 2.00 & 2.27 & 6.73 & 8.29 & 13.29 \\
\hline Export & - & - & - & - & $\begin{array}{c}100 \\
(9,800 \text { to })\end{array}$ & 1.23 & 2.26 \\
\hline -Vegetables & $100(600$ to $)$ & 6.67 & 6.67 & 3.33 & 5.00 & 12.00 & 14.51 \\
\hline -Fruits (sour cherries, cherries) & - & - & $\begin{array}{c}100 \\
(200 \text { to })\end{array}$ & 1.50 & 2.50 & 5.00 & 1.70 \\
\hline $\begin{array}{l}\text {-Spontaneous flora collection, } \\
\text { out of which: }\end{array}$ & $100(200$ to $)$ & 2.00 & 1.50 & 1.60 & 22.50 & 83.74 & 124.81 \\
\hline Export & - & - & - & - & $\begin{array}{c}100 \\
(3800 \text { to })\end{array}$ & 3.74 & - \\
\hline -Other crops & $100(2$ to $)$ & 150.00 & 400.00 & 450.00 & 600.00 & 3175.00 & 5520.50 \\
\hline
\end{tabular}

Source: Own calculations based on MADR and INS database

In the Table 3, we present the evolution of the organic agriculture in last years, after the accession into EU.

Table 3. Areas and producers in organic agriculture after EU accession (2007-2012)

\begin{tabular}{|l|c|c|c|c|c|c|}
\hline \multicolumn{1}{|c|}{ Indicator } & $\mathbf{2 0 0 7}$ & $\mathbf{2 0 0 8}$ & $\mathbf{2 0 0 9}$ & $\mathbf{2 0 1 0}$ & $\mathbf{2 0 1 1}$ & $\mathbf{2 0 1 2}$ \\
\hline No. of farmers & 3834 & 4191 & 3228 & 3155 & 9703 & $26736^{* * *}$ \\
\hline Area in arable area (ha) & 65112.0 & 86454.0 & 110014.4 & 148033.5 & $151109.0^{*}$ & 164936.9 \\
\hline $\begin{array}{l}\text { Area - permanent crops of pastures } \\
\text { and fodder (ha) }\end{array}$ & 57600.0 & 46006.5 & 39232.8 & 31579.1 & 78198.0 & 105835.6 \\
\hline $\begin{array}{l}\text { Area - permanent crops of orchards } \\
\text { and grapevine (ha) }\end{array}$ & 954.0 & 1518.0 & 1869.4 & 3093.0 & 4166.0 & 9430.0 \\
\hline Spontaneous flora collection (ha) & 58728.0 & 81279.0 & 88883.4 & 77294.4 & $80120.0^{*}$ & 1088641.3 \\
\hline
\end{tabular}

Note: $*$ = estimations; $* *=$ producers, processors, traders, importers, exporters

Source: MADR database - County Agricultural Departments (www.madr.ro) 
According to the last data from MADR, in 2012 the areas under organic agriculture increased fantastic, due to the facilities accorded by the ministry and the EU funds at the producers' disposal, on one side and on the other side due to change of the classification of organic producers (this was mainly due to the existing support measures for the period conversion granted under art. 68 of Regulation (EC) laying nr.73/2009 common rules for direct support schemes for farmers under the common agricultural policy and establishing certain support schemes for farmers). In the same time, there are estimations that the number of organic operators increased in the same way, nowadays being over 10.000, at the level of $2011^{7}$ and over $26.000^{8}$, at the level of 2012.

\section{Demand and trade of organic products in Romania}

Following the presentation of these statistical data, the organic farming could be considered as a dynamic sector in Romania (Voicilas, 2007b), with an increasing trend in recent years. As a result, the organization of the marketing (www.agricultura-ecologica. ro) of the organic products is an increasingly important element in this sector. The sale of organic products can take place directly from the farm, or through the traders registered at MADR. The organic products are found both in the large store network and in the smallspecialized shops.

On Romanian market, organic product range is quite limited. On national market, in 2011, were sold: vegetables and fruits produced, processed fruits and vegetables, herbal teas, bread, pasta, flour products, processed cow and sheep milk (butter, feta cheese), eggs, oil, wine made from grapes certified organic, processed soy products, honey, etc. Most food is brought from abroad (canned vegetables, fruits, bread). Bestsellers organic products are milk, eggs, yogurts, fruits, vegetables, and meats.

Immediately after joining the EU, total sales of organic products in Romania reached about 10 million, which represents less than $1 \%$ of the retail market and very little compared to $5-6 \%$, as is the European average (2008). At present, the estimations of total sales of organic products, made by MADR are double.

The organic products are found both in the large store network and in the small-specialized shops. At the beginning of the year 2007, only two shop networks were registered at MADR: the shop "BIOCOOP" (Sibiu) and the shop Naturalia (www.naturalia.ro), with units both in Bucharest and in the county Ilfov (Voluntari). After one year, there were 6 shops. At the end of 2012 there are already 25 shops registered.

Except for the processors that have their own presentation shops, not all shops respect the storage/handling/presentation rules for organic products. The organic products are found in the same place with the conventional products; they are handled and stored together. In different studies (e.g. Expert Group study, 2007), the authors show that, on the domestic market there is confusion between "natural product" and "organic product" (most often

7 www.eco-ferma.ro/performantele-agriculturii-ecologice/

8 http://old.madr.ro/biofach2013/Anexa_sector_ecologic_romana.pdf

EP 2014 (61) 2 (381-395) 
maintained by the producers of the former), which makes it more difficult to promote an organic product under the conditions of the price difference.

The sale on the domestic market is through the wholesale networks Metro, Selgros mainly by retail shops. The main stores that introduced organic products in their assortment of goods are: Carrefour, Cora, Gima, La Fourmi, Mega Image, Nic, Primavera and OK.

An important role in market promotion and obtaining new market shares and segments of consumers is represented by the marketing activity. The presentation of products, the beneficial effects upon the human body, the gains obtained by buying clean and healthy products, even though they are more expensive than the conventional products, as well as consumers growing aware of their importance, are the main concerns that the producers and sellers of organic products should have in their development policy. The participation in exhibitions, fairs and other national and international manifestations is a modality to present the organic products and to establish new contacts for marketing these products. It is only a promotion modality among several possibilities, with a special impact upon consumers.

The fact that the organic products have a market in Romania is proved by imports, which are doubling almost every year. In 2007, the market of organic products was estimated at 2.5 mil EUR ( 1 mil EUR more than in 2006, before accession). At that time, about $70 \%$ from the organic products on the market were from import. Meantime, the imports decreased and at the end of 2010 the exports were about 150 mil. Euro and imports were about 35 mil. Euro (Eco Ferma, 2014, www.eco-ferma.ro/performantele-agriculturii-ecologice/).

Previous analysis reveal that, in the period $2006-2007$ only $30 \%$ of the organic production was sold on the domestic market and the rest was exported (Expert Group study, 2007). The main organic products sold through the organized commercial network were eggs and dairy products. In comparison, in 2012 a percentage of approximately $70-80 \%$ of organic products was exported.

The Romanian organic products are mainly exported to Western Europe (Germany, Italy, Switzerland and Netherlands for example) and attempts are being made to penetrate the US market. The wild berries, either organic or non-organic, have a much higher export price, and the price is even higher if these are organically certified. Main exported products are: cereals, oilseeds and protein, berries, herbs, honey and sheep cheese.

\section{Trends and key issues on Romanian market}

The reaching of the export targets is linked to other objectives as well (on the short, medium and long-term), which can contribute to the improvement of the competitiveness of the Romanian organic sector in the next period:

- The increase in the number of operators in this sector, receiving financial support from the Romanian Government Programs;

- Increase of the role of the non-governmental organizations (NGOs) in this sector through programs for the development of trade with organic products; 
- Increase in the number of exporters who are actively involved in programs for organic agricultural trade development in the less-favoured areas;

- Support provided to organic commercial farms, so as to be more active on the market;

- The association of the small organic farmers so as to co-operate in the marketing of organic products;

- The increase in the number of municipal and regional organizations directly involved in the implementation of the National Export Strategy in its initial stage;

- The increase in the number of local processing units and foreign direct investment projects;

- The increase of investments in related activities in rural areas;

- The increase in the number of employees in the exporting units which are implementing the organic farming regulations;

- The increase of investments in the activities related to exportable organic products from the less developed rural areas;

- The increase of the organic farm output;

- The increase in the number of new companies involved in export activities with primary and processed organic agricultural products;

- The increase in the number of optimal operation modules by the association of crop and livestock farms;

- The development of processing capacities for the organic farming sector;

- Capacity improvement in terms of products and value added;

- The development of services oriented towards the export of organic products;

- The diversification of the exportable cultivated species (for example: vegetables, fruits) and of the range of processed products (e.g: bakery and pastry products);

- Increase in the number of new approved investment projects.

Unfortunately, not all the producers are satisfied with the evolution of this market and with the government's involvement in the activity to support organic farming. In the opinion of some farmers who had initiatives in this field, organic agriculture became a non-efficient business in Romania, not because the outlet is not large enough, but rather because the government has not shown interest in this activity so far; on the other hand, this activity was given as an example of opportunity to conquer the foreign markets. The lack of financial support from the state, in addition to the extreme weather phenomena in the last years, is the main factor which determines the producers to think giving up their business. In many reports made by the producers or in the communications at the scientific events organized by them, it is mentioned that farmers are confronted with the problem of higher production costs as well as with the problem of products distribution.

The problem of the ratio of the production cost to the price of the product is not the only problem for organic farmers. The consumer is interested more in the price than in the quality of the product, and this constrains the development of the sector. 
As always happens in such conflicts, on the other side, of the state institutions, the announcements are optimistic, satisfactory, and even praiseworthy. All governmental statements and the official documents show the favourable evolution of this sector and government's active implication in its development. For example, the documents elaborated by Romania's Government in the last years regarding the strategy in this field in the future, comprise concrete references on the next steps and have clearly identified objectives. We can easily remember what was stated in the past, before accession: Romania has great opportunities for promoting and developing organic farming due to its large agricultural land area, i.e. 14.9 mil ha and its non-polluted soils; the increase of organic farmers' participation to the economic events in the country and abroad (BioFach, 2006). By the examination of the valoric chain and of the consumers' requirements on the world market, the following critical success factors could be identified: price, assortments, package, branding, and availability.

\section{Quality schemes in Romania: PGI case study for "Magiun Topoloveni"}

"Topoloveni" plum jam certification has protected geographical indication (PGI) in Europe since 8 April 2011, the first award of its kind received by a Romanian traditional product. "Topoloveni" natural plum jam is produced according to a recipe kept from 1914. The product holds the title of Supplier of HM Royal House of Romania. It is still the only PGI in Romania.

For Romania, the European Commission approved a program to promote agricultural products in Switzerland, Norway and the Russian Federation, worth a total of approximately 4.2 million, of which the relevant part of Romania is 981.613 Euro. The program is run by the manufacturer jam "Topoloveni" - SC Sonimpex Topoloveni Ltd, together with a consortium of producers in Greece.

Leads the way, an example to be followed - "Magiun Topoloveni", plump jam, represents the Romanian first product certified by the EU and now the first to be accepted by the EU for promotion. In an interview with the representatives of the company many complains could be recorded regarding the abusive clauses in the contracts with the retails chains, such as for example Cora hypermarkets. "If the stock of "Topoloveni" jam ends, then, the hypermarket can take other product and I have to pay for the product listing" said the company's representative, referring to the clause in the contract proposed by the hypermarket network. At the same time the representative of the company explained that the company's product is a traditional geographical indication, recorded at OSIM (National Mark Registration Office) and recognized in the EU, so it can not be replaced with any type of product. In the opinion of the owners of "Topoloveni" jam, traditional product should be untouchable. "You can not make its mark on traditional product", said the representatives of the company, adding that in some countries hypermarkets are obliged to purchase traditional products.

The representative of the Inter-professional organization in the fruits and vegetable sector Romconserv, said in his turn that the producers of canned fruits and vegetables are required by some retailers to ensure continuity of stock in the shop for a year. 
On the other hand, in Romania there are many manufacturers who agreed to sell their products under private brand retails to major retailers. "We are small producers who agreed to produce inferior quality merchandise under the mark/label of big retailers. Already the traditional brands are disappearing. "Future generations will not know how to speak Romanian," said the representative of "Topoloveni" jam producer referring to the name of foreign products. In response, supermarket representatives said that the clause referred the representative of "Topoloveni Magiun" is standard between a distributor and a manufacturer and the honouring of delivery orders by the producer, so the shelves will not be empty. "The reason for the failure to reach a trade agreement on "Topoloveni" jam is called the producer purchase price that would be transformed into a product too expensive for the hypermarket clients," added the hypermarket network representative. On the other side it should not be neglected that PGI products like organic products are meant for a selective client thus the hypermarket argument cannot be sustained and prevails consumers from having the chance to choose their preferred products even on a temporary basis.

Similar disagreements can be noticed also between "Topoloveni" jam manufacturer and other retail network, a discounter (Lidl) who has own brand of "jam" which it seems does not meet technological standards available in Romania and European regulations and it is sold at dumping prices.

\section{Conclusions}

We can say that, two factors are adjudged to be responsible for consumer demand to be concentrated in the most affluent countries of the world. The price premium of organic products restricts demand to countries where consumers have high purchasing power. This explains why most sales are in countries where there is a sizeable middle-class in the population. The second factor is education and more specifically awareness of organic products. As consumers become more educated and informed of food issues, they are more inclined to buy organic products whether it is because of factors like food safety, concern for the environment, or health reasons.

As production of organic crops increases across the globe, regional markets are also expected to develop in which organic farmers will produce organic products for consumers in their region. This is expected to stimulate sales of organic products in many developing countries, especially in countries like Brazil, China, India, and South Africa where economic development is increasing at a rapid rate and a more educated and affluent middle-class of consumers is developing (Willer, Yussefi, 2004).

The main conclusions resulted from this analysis, as regards the ways which can contribute to the improvement of the competitiveness of the Romanian organic sector in the next period, considered an important niche market, are, as follows: the increase of the number of operators in this sector, receiving financial support from the Romanian Government Programs; the association of the small organic farmers so as to co-operate in the marketing of organic products; an increase in the number of municipal and regional organizations directly involved in the implementation of the National Export Strategy in its initial stage; an increase 
in the number of foreign direct investment projects and investments in related activities in the rural area; an increase and diversification of the organic farm output; capacity improvement in terms of products and value added; the development of services.

We can conclude that, even if there are countries in EU with traditions in the field, which has a rich experience and many registered products like Italy, Spain or Hungary, even if the theory and the businessmen accept that the products are important for producers and consumers in the same time, in Romanian reality all these aspects are not present and cannot be verify. The main reasons of this fact are: the lack of initiative from producers, weak communication with the authorities/institutions, a weak organization of producers and lack of perception of their advantages from the business and maybe, the big volume of work necessary to fulfil the legal requirements.

The findings on organic food markets and the EU quality schemes applied in Romania are also important for further research, but we must underline that, there is still little information available with respect to the PDO/PGI/TSG products, even in other EU countries and this represents the main barrier.

\section{Literature}

1. Alboiu, C. F., Bojnec, ŠS., Čechura, L., Dries, L., Filipovic, J., Gorton, M., Hockmann, H., Levkovych, I., Malá, Z., Malý, M., Ognjanov, G., Pacca, L., Stojanovic, Z., Voicilas, D. M. (2014): Working paper "EU QUALITY SCHEMES: market potential for products produced and processed”, www.compete-project.eu

2. Voicilas, D. M. (2007a): Organic farming, in Ionel, I. (Ed.): Non-conventional farming economics (pp. 70-125), Romanian Academy, Institute of Agricultural Economics, Terra Nostra Publishing House, Iasi, Romania.

3. Voicilas, D. M. (2007b): Alternatives of rural development-organic farming, in: Multifunctional agriculture and rural development - Rural values preservation, Proceedings, IAE Belgrade, Serbia.

4. Willer, H., Yussefi, M. (Eds.), (2004): The World of Organic Agriculture-Statistics and Emerging Trends, $6^{\text {th }}$ revised edition, International Federation of Organic Agriculture Movements, Bonn, Germany.

\section{Databases:}

- INS Database (www.insse.ro $)$

- MADR Database (www.madr.ro)

- National Export Strategy for the period 2005-2009 (www.dce.gov.ro/SNE/SNE sept_2005.htm)

\section{Web pages:}

- www.eco-ferma.ro/performantele-agriculturii-ecologice/, (Eco Ferma, 2014).

- http://ec.europa.eu/agriculture/quality/schemes/index en.htm 
· http://eur-lex.europa.eu/LexUriServ/LexUriServ.do?uri=OJ:L:2012:343:0001:0029:en

- www.onpterbv.ro/, (Oficiul National al Produselor Traditionale si Ecologice Romanesti (National Office for Traditional and Organic Romanian Products)).

\section{Annex}

Table 4. Romanian organizations in organic agriculture, rural development, environmental protection, and durable development (2012)

\begin{tabular}{|c|c|}
\hline Name of Organization & Location/web \\
\hline Federația Națională de Agricultură Ecologică & Cluj/www.fnae.ro \\
\hline Organizația profesională „,Agroecologia” & Cluj/www.agroecologia.ro \\
\hline Asociația bioagricultorilor din România „BIOTERRA” & Cluj/www.greenagenda.org/bioterra \\
\hline Asociația Română pentru Agricultură Durabilă & Călăraşi/www.agriculturadurabila.ro \\
\hline Asociatia operatorilor din agricultura ecologica BIO ROMANIA & Calarasi/www.asociatiabioromania.ro \\
\hline Asociația Bioavicultorilor din România - BIOAVIROM & Ilfov/www.bioavirom.ro \\
\hline Societatea pentru o Agricultură Ecologică & Cluj \\
\hline Asociația de Protecția mediului şi agricultură ecologică „TER” & Bucureşti/www.ter.ro \\
\hline Fundația „Mama Terra” & Bucureşti \\
\hline „Asociația Națională a Consultanților din Agricultură” & Bucureşti \\
\hline Fundația Academică pentru Progres Rural „TERRA NOSTRA” & Iaşi \\
\hline „Societatea ecologistă din Maramureş” & Maramureş \\
\hline „Grupul Ecologic de Colaborare Bucovina” & \begin{tabular}{|l|} 
Suceava \\
\end{tabular} \\
\hline Societatea „Avram Iancu” & Cluj \\
\hline Fundația „Operațiunea satelor româneşti” & Bacău \\
\hline „Clubul Ecologic Transilvania” & Cluj \\
\hline „Fundația Rurala România” & Timiş \\
\hline „Bioclub Cluj” & Cluj \\
\hline „Grupul Grădinarilor Biodinamici” & Mureș \\
\hline ,Asociația Romana de Bioagricultura Aplicată” & Arad \\
\hline „Centrul de Consultanță Ecologică Galați” & Galați \\
\hline ,Asociația pentru Protecția Mediului si a Naturii” & Mureş \\
\hline Fundația „Divers Eco” & Maramureş \\
\hline Fundația „Noema Consulting” & Cluj \\
\hline Asociația Albina & Bucureşti/http://www.ere-concept.com \\
\hline \multicolumn{2}{|l|}{ Asociația pentru Protecția Mediului şi Prezervarea Resurselor } \\
\hline Asociația „,Terra Verde” & Bucureşti \\
\hline \multicolumn{2}{|l|}{ Asociatia Romano-Italiana AgriEcològica } \\
\hline Asociatia Romana de Bioagricultura Aplicativa - Ferma Ecologica Familiala & Arad \\
\hline Asociatia EcoLogic & Maramureş \\
\hline Asociatia bioagricultorilor din Moldova,,BIOMOLD” & Bacau \\
\hline
\end{tabular}

Source: MADR (Romania) 